\title{
First Principles in Translation: The Axiom of Self-Interest from Adam Smith to Jean-Baptiste Say
}

\author{
Pierre Force
}

The reception of Adam Smith's Wealth of Nations in France and in Continental Europe was very much tied to the fortunes of the French translation that Germain Garnier (1754-1821) published for the first time in 1802 . This translation was quickly accepted as authoritative. In 1803, JeanBaptiste Say praised Garnier's translation as "the only one that is worthy of the original" (xxiij, n. 1). ${ }^{1}$ The abundance of endnotes and the extensive preface clearly designated La richesse des nations as a canonical text. In the 1843 edition of the Garnier translation, Adam Smith's work reached the final stage in the process of canonization. As Kenneth Carpenter (2002, 1xi) puts it, this edition "served as a foundation work for the academic discipline of economics in France, no doubt to some extent even

Correspondence may be addressed to Pierre Force, Department of French, 517 Philosophy Hall MC 4902, Columbia University, 1150 Amsterdam Avenue, New York, NY 10027. An earlier version of this paper was presented at the Gimon Conference on French Political Economy, 1650-1848 (Stanford University, April 2004). I thank Keith Baker for his kind invitation, as well as Gilbert Faccarello and Philippe Steiner for their comments and suggestions. I also thank Keith Tribe for his invaluable advice on how to trace the reception of the Garnier translation.

1. "La traduction de Smith par Garnier est la seule qui soit digne de l'original." All quotes preserve the original spelling.

2. The 1843 version of the Garnier translation remained the standard edition of The Wealth of Nations in French until the 1995 translation by Paulette Taieb. For a comprehensive study of the reception of Adam Smith in English, French, German, Russian, Polish, Spanish, Portuguese, Japanese, and Chinese, see Tribe and Mizuta 2002.

History of Political Economy 38:2 DOI 10.1215/00182702-2005-005

Copyright 2006 by Duke University Press 
internationally."2 The editor, Adolphe Jérôme Blanqui (1798-1854), who had succeeded Jean-Baptiste Say as the holder of the political economy chair at the Conservatoire des arts et métiers, included notes and comments by all the principal economists in Europe: Say, Bentham, Malthus, Ricardo, Buchanan, Sismondi, and von Storch, among others. As a result, The Wealth of Nations "was no longer an English effort, no longer an English and French work, no more just the labor of two people, but rather a work of many hands from throughout Europe, all people working to develop a body of knowledge" (Carpenter 2002, lxii). In the first half of the nineteenth century French was still the language of choice for intellectual exchange, and many economists were more comfortable reading Smith in French rather than in the original English. As Keith Tribe (2003, 162) explains, Smith's ideas "generally became known through the work of translators and commentators," the most important one being JeanBaptiste Say, who "wrote in a language that educated Europeans could read and wrote in a style that was considered more accessible than that of Smith." Therefore, the dissemination of Smith's ideas occurred in no small part through Say's commentary and interpretation of the Garnier translation. ${ }^{3}$ Two examples of those educated Europeans who read Smith in Garnier's French were Storch and Marx. Heinrich von Storch, the German-Russian economist who composed his Cours d'économie politique for the sons of the Emperor of Russia in 1815, lifted large segments of his text from Garnier's translation and from Say's Traité d'économie politique. $^{4}$ (After Storch accused Say of plagiarism, Say [1825] published a terse note in the Revue encyclopédique to set the record straight.) Karl Marx became acquainted with political economy in 1843-44 through extensive readings of Say's Traité and Garnier's translation of The Wealth of Nations. ${ }^{5}$

\section{Garnier's Choice of Words}

Given the importance of the Garnier translation, one may suspect that Garnier's understanding of Smith played a tacit but significant role in the

3. Say himself became acquainted with Smith's work in the original English in the 1790s.

4. See for instance volume 1, pages 72-73, of Storch 1815, where Smith's famous passage on the baker and the butcher appears (without acknowledgment) in Garnier's translation.

5. His readings also included Ricardo, Mill, and McCulloch, all in French. See Marx 1982. Also see Marx's excerpts from the Garnier translation of Smith (with commentary and partial translation into German) in Marx 1981. Marx used the original 1802 edition. 
development of economic science in Continental Europe. ${ }^{6}$ This will seem especially relevant if we recall that several translations of The Wealth of Nations had been published before, and that these translations differ from Garnier's in some important respects. In this article, I will focus on the translation of one word: self-love. This word appears only twice in the book, but both occurrences are in the same strategic place: the oft-quoted passage in the second chapter of book 1, where Smith ([1776] 1976, I.ii.2) discusses the causes of the division of labor (occurrences of selflove in bold):

But man has almost constant occasion for the help of his brethren, and it is in vain for him to expect it from their benevolence only. He will be more likely to prevail if he can interest their self-love in his favour, and shew them that it is for their own advantage to do for him what he requires of them. Whoever offers to another a bargain of any kind, proposes to do this. Give me that which I want, and you shall have this which you want, is the meaning of every such offer; and it is in this manner that we obtain from one another the far greater part of those good offices which we stand in need of. It is not from the benevolence of the butcher, the brewer, or the baker, that we expect our dinner, but from their regard to their own interest. We address ourselves, not to their humanity but to their self-love, and never talk to them of our own necessities but of their advantages.

Here is how Garnier (1802) translates the passage. Translations of selflove are in bold, and the italics are Garnier's:

Mais l'homme a presque continuellement besoin du secours de ses semblables, et c'est en vain qu'il l'attendrait de leur seule bienveillance. Il sera bien plus sûr de son fait en s'adressant à leur intérêt personnel, et en leur persuadant qu'il y va de leur propre avantage de faire ce qu'il souhaite d'eux. C'est ce que fait celui qui propose à un autre un marché quelconque; le sens de sa proposition est ceci: Donnez-moi ce dont j'ai besoin, et vous aurez de moi ce dont vous avez besoin vous-même;

6. Garnier's understanding of Smith was not only influential through the French translation. The 1805 Glasgow edition of The Wealth of Nations (printed for J. \& J. Scrymgeour at the University Press) included an English version of Garnier's commentary on Smith. This edition was reprinted many times. According to Keith Tribe, "It can be said with some justification that during the first half of the nineteenth century the most consistently accessible guide to Wealth of Nations in English was that of Germain Garnier" (Tribe and Mizuta 2002,37). 
et la très-majeure partie de ces bons offices qui nous sont si nécessaires, s'obtiennent de cette façon. Ce n'est pas de la bienveillance du boucher, du marchand de bière ou du boulanger, que nous attendons notre dîner, mais bien du soin qu'ils apportent à leurs intérêts. Nous ne nous adressons pas à leur humanité, mais à leur égoïsme; et ce n'est jamais de nos besoins que nous leur parlons, c'est toujours de leur avantage.

Smith uses self-love twice, but Garnier chooses to translate each occurrence differently: intérêt personnel and égoüsme. This choice of words may not seem particularly problematic to the modern French reader, who is used to reading Smith in Garnier's translation. However, Garnier's choice was a deliberate departure from previous practice. In all French translations published before Garnier, self-love was translated as amour-propre. The anonymous translation of 1778 reads: "s'il peut intéresser leur amourpropre en sa faveur" and "nous ne nous adressons pas à leur humanité, mais à leur amour-propre"7 In Blavet's 1779 translation, the same passages are rendered as "en intéressant leur amour-propre en sa faveur" and "ce n'est point à leur humanité, mais à leur amour-propre que nous nous adressons." ${ }^{8}$ A small variation can be observed in Roucher (1790): "s'il peut intéresser leur amour propre en sa faveur" and "nous nous adressons, non pas à leur humanité, mais à leur amour pour eux-mêmes" Only the unpublished translation by Abbé Morellet deviates from the norm. The first occurrence reads: "lorsqu'il peut les disposer à ce qu'il désire par la vüe de leur propre intérêt." Interestingly, Morellet skips the second occurrence of self-love. He translates: "Nous ne nous adressons pas à leur humanité et nous ne leur parlons pas de nos besoins, mais de leur avantage." 9

Garnier's decision to use intérêt personnel instead of amour-propre was perceived as significant at the time. In his review of the Garnier translation, Martial Desrenaudes (1802) gave a list of what he said were errors in the latest edition of Blavet's translation (1800), accompanied by the cor-

7. See the "bibliothèque virtuelle" of PHARE (Pôle d'histoire de l'analyse et des representations économiques) for an excellent electronic edition of all the passages I am discussing here (phare.univ-paris1.fr/textes/Smith/WN/index.html). I thank the editor of the site, Paulette Taieb, for her patience and generosity in answering my questions.

8. This translation by Abbé Blavet appeared initially in serialized fashion in the Journal de l'agriculture, des arts, et du commerce et des finances (1779-80).

9. Abbé André Morellet, ms. 2540, Bibliothèque municipale de Lyon, quoted by Paulette Taieb at phare.univ-paris1.fr/textes/Smith/WN/index.html. 
rect translation in Garnier. The list includes the translation of self-love: "A la page 25, on lit: amour propre, au lieu de, intérêt personnel (Selflove)" (quoted in Carpenter 2002, 211). According to this early reviewer, translating self-love as amour-propre had been a mistake. The proper translation, given for the first time by Garnier, was intérêt personnel.

\section{A Short History of Self-Love}

What are the implications of Garnier's decision? In many ways, past uses of a word are still present in its current use. Amour-propre and intérêt personnel are words with different histories and distinct connotations. They do not belong to the same philosophical and literary traditions. The connotations of amour-propre in seventeenth- and eighteenth-century moral philosophy are rich and complex. Amour-propre is the translation of a technical term used by Renaissance humanists, philautia. It is used by Pascal, La Rochefoucauld, Nicole, Bayle, Voltaire, and Rousseau, among many others. ${ }^{10}$ The English equivalent of amour-propre throughout the seventeenth and eighteenth centuries, from Hobbes to Shaftesbury, Mandeville, Joseph Butler, and Hume, is self-love. In other words, when French readers see self-love in Shaftesbury or Hume, they read amour-propre, and when English readers see amour-propre in Nicole or Bayle, they read self-love. The words amour-propre and self-love carry with them the Augustinian paradox that was initially formulated in La Rochefoucauld's Maximes (1665), and subsequently popularized by Mandeville's Fable of the Bees (1732): self-love (a vice) is the root of human virtues; private vices produce public benefits. The Fable of the Bees produced a flurry of responses and refutations. Virtually every moral philosopher in the first half of the eighteenth century felt compelled to articulate a response to Mandeville's paradox. ${ }^{11}$ Two questions were at stake in those debates: Is self-love a vice? Is self-love the cause of all human actions? For authors in the Augustinian tradition like La Rochefoucauld, Bayle, and Mandeville, both questions were answered in the affirmative: self-love is a vice, and it is the cause of all human actions, except when God's grace is at work. On the contrary, for Hume and Smith, self-love is neither a vice nor the cause of all human

10. On the history of the words philautia and amour-propre, see Fuchs 1977.

11. For an overview of the debate on self-love as a first principle, see Force 2003, especially chapters 1 and 2 . 
actions. In The Theory of Moral Sentiments, self-love is described as a morally neutral category, and the first sentence of the book alludes to what Hume ([1751] 1983, 90) once called the "selfish hypothesis" in order to refute it: "How selfish soever man may be supposed, there are evidently some principles in his nature, which interest him in the fortune of others" (Smith [1759] 1976, I.i.1). In the system that Smith develops in The Theory of Moral Sentiments, human behavior is derived not from one, but two principles: self-love and sympathy. As I argued in my recent book, Self-Interest before Adam Smith (2003), Smith's response to Mandeville in The Theory of Moral Sentiments is very close to the one Rousseau put forward a few years before in the Second Discourse, especially with regard to first principles. Both authors respond to Mandeville's exposition of the selfish hypothesis by singling out pity, a subsidiary element in Mandeville's narrative, and elevating it to the status of a first principle. As first principles, self-love and sympathy in Smith correspond to amour de soi and pitié in Rousseau (Force 2003, chap. 1). In France, aside from Rousseau's work, the notion that self-love is the cause of all or most human actions was rarely challenged. The focus was on refuting the idea that self-love is a vice. For instance, in the "Amour-propre" article of the Dictionnaire philosophique, Voltaire ([1764] 1954) presents the selfish hypothesis as universally acknowledged and self-evident:

Ceux qui ont dit que l'amour de nous-mêmes est la base de tous nos sentiments et de toutes nos actions ont donc eu grande raison dans l'Inde, en Espagne, et dans toute la terre habitable: et comme on n'écrit point pour prouver aux hommes qu'ils ont un visage, il n'est pas besoin de leur prouver qu'ils ont de l'amour-propre. Cet amour-propre est l'instrument de notre conservation; il ressemble à l'instrument de la perpétuité de l'espèce : il nous est nécessaire, il nous est cher, il nous fait plaisir, et il faut le cacher. ${ }^{12}$

On the other hand, Voltaire is vehement in his criticism of the notion that self-love is a vice. In another article in the Dictionnaire philosophique, he savages Jacques Esprit, the author of the treatise On the Falsity of Human

12. "Those who have said that the love of ourselves is the basis for all our feelings and all our actions have been quite right in India, in Spain, and all across the inhabitable earth. As one does not write to persuade men that they have a face, there is no need to give them proof that they possess self-love. Self-love is the instrument of our preservation; it resembles the instrument of the perpetuation of the species. We need it, it is dear to us, it gives us pleasure, and we must hide it." 
Virtues, for having written that virtues cannot be genuine because they are based on "amour-propre":

Quand le duc de La Rochefoucauld eut écrit ses pensées sur l'amourpropre, et qu'il eut mis à découvert ce ressort de l'homme, un monsieur Esprit, de l'Oratoire, écrivit un livre captieux, intitulé: De la Fausseté des vertus humaines. Cet Esprit dit qu'il n'y a point de vertu; mais par grâce il termine chaque chapitre en renvoyant à la charité chrétienne. Ainsi, selon le sieur Esprit, ni Caton, ni Aristide, ni Marc-Aurèle, ni Épictète n'étaient des gens de bien; mais on n'en peut trouver que chez les chrétiens. Parmi les chrétiens, il n'y a de vertu que chez les catholiques; parmi les catholiques, il fallait encore en excepter les jésuites, ennemis des oratoriens; partant, la vertu ne se trouvait guère que chez les ennemis des jésuites. . . . Une telle insolence révolte. Je n'en dirai pas davantage, car je me mettrais en colère. ${ }^{13}$

Jacques Esprit's book was a theological exposé that turned the Augustinian assumptions of La Rochefoucauld's Maximes into a systematic and explicit doctrine based on original sin and the fall of man. Because the Augustinian theology of the Maximes remained implicit, Voltaire and the philosophes could very well perform a secular reading of La Rochefoucauld and endorse his illustration of the selfish hypothesis while denying that self-love was a vice. No such reading was possible with Esprit, who became a polemical target.

Another Port-Royal author who met the same fate was Nicole. In the "Intérêt" article of the Encyclopédie, Saint-Lambert (1751-72) vilified him for writing that "amour-propre" could not be the source of virtues:

L'amitié sera toujours une vertu, quoiqu'elle ne soit fondée que sur le besoin qu'une âme a d'une autre âme.

La passion de l'ordre, de la justice, sera la première vertu, le véritable héroïsme, quoiqu'elle ait sa source dans l'amour de nous-mêmes.

13. "After the duke of La Rochefoucauld wrote his thoughts on self-love and uncovered this motive of human action, a certain Monsieur Esprit, of the Oratory, wrote a specious book titled On the Falsity of Human Virtues. This Esprit says there is no such thing as virtue, but he does us the favor of ending each chapter by mentioning Christian charity. Thus according to Monsieur Esprit, neither Cato, nor Aristides, nor Marcus Aurelius, nor Epictetus, were good people; such people can only be found among Christians. Among Christians, only Catholics have virtue; among Catholics, Jesuits (enemies of the Oratorians) must be excluded; so much so that virtue can only be found among the Jesuits' enemies. . . . Such arrogance is revolting. I will not say more, because it would make me lose my temper." Voltaire [1764] 1954, art. "Fausseté des vertus humaines." 
Voilà des vérités qui ne devraient être que triviales et jamais contestées; mais une classe d'hommes du dernier siècle a voulu faire de l'amour-propre un principe toujours vicieux; c'est en partant d'après cette idée que Nicole a fait vingt volumes de morale, qui ne sont qu'un assemblage de sophismes méthodiquement arrangés et lourdement écrits.

Pascal même, le grand Pascal, a voulu regarder en nous comme une imperfection ce sentiment de l'amour de nous-mêmes que Dieu nous a donné. ... M. de la Rochefoucauld qui s'exprimait avec précision et avec grâce, a écrit presque dans le même esprit que Pascal et Nicole; ... Ce livre de M. de la Rochefoucauld, celui de Pascal, qui étaient entre les mains de tout le monde, ont insensiblement accoutumé le public français à prendre toujours le mot d'amour-propre en mauvaise part; et il n'y a pas longtemps qu'un petit nombre d'hommes commence à n'y plus attacher nécessairement les idées de vice, d'orgueil, etc. ${ }^{14}$

This passage is particularly interesting for our purposes because it spells out the connotations of the word amour-propre in the middle of the eighteenth century. The word is still associated with the Augustinian critique of virtues, which had become almost a matter of conventional wisdom with the success of Pascal's Pensées, La Rochefoucauld's Maximes, and Nicole's Essais de morale. At the same time, Saint-Lambert presents the encyclopédistes as a small group of enlightened men whose critique of the critique of virtues was only beginning to change the connotations associated with the word amour-propre.

A common practice among eighteenth-century philosophers consisted in presenting philosophical disputes as semantic ones. Near the beginning of De l'esprit, in a chapter titled "On the Abuse of Words," Helvétius

14. "Friendship will always be a virtue, even though it is based on the need a soul has for another soul.

Love of order, justice, will always be the prime virtue and the true heroism, even though it has its source in the love of oneself.

These truths should be commonplace and never questioned, but a certain group of people in the last century meant to turn self-love into an ever-maligned principle.

This was the basis on which Nicole made twenty volumes of morals, which are but a collection of methodically arranged and gracelessly written sophisms.

Pascal himself, the great Pascal, meant to view as an imperfection this love of ourselves that God gave us. . . . M. de La Rochefoucauld, who expressed himself with precision and grace, wrote nearly in the same spirit as Pascal and Nicole. . . . La Rochefoucauld's book, and Pascal's, which were in everybody's hands, have gradually accustomed the French public to take the word self-love always in a bad sense. It is only recently that a small number of men have begun to dissociate it from the ideas of vice, pride, etc." 
(1758, I, IV) discusses the meaning of amour-propre in La Rochefoucauld. He claims that readers have misunderstood the word by associating it with vices like pride and vanity:

Lorsque le célebre M De La Rochefoucault dit que l'amour-propre est le principe de toutes nos actions, combien l'ignorance de la vraie signification de ce mot amour-propre ne souleva-t-elle pas de gens contre cet illustre auteur? On prit l'amour-propre pour orgueil et vanité; et l'on s'imagina, en conséquence, que M De La Rochefoucault plaçoit dans le vice la source de toutes les vertus. Il étoit cependant facile d'appercevoir que l'amour-propre, ou l'amour de soi, n'étoit autre chose qu'un sentiment gravé en nous par la nature; que ce sentiment se transformoit dans chaque homme en vice ou en vertu, selon les goûts et les passions qui l'animoient; et que l'amour-propre, différemment modifié, produisoit également l'orgueil et la modestie. ${ }^{15}$

While he claims La Rochefoucauld as a predecessor, Helvétius, presumably because of the moral and religious connotations still attached to the word, never uses amour-propre in his own doctrine. Instead, he uses intérêt personnel (self-interest):

Quel homme, en effet, s'il sacrifie l'orgueil de se dire plus vertueux que les autres à l'orgueil d'être plus vrai, et s'il sonde, avec une attention scrupuleuse, tous les replis de son ame, ne s'appercevra pas que c'est uniquement à la maniere différente dont l'intérêt personnel se modifie, que l'on doit ses vices et ses vertus? Que tous les hommes sont mus par la même force? ${ }^{16}$

Helvétius agrees with his fellow encyclopédistes that the word amourpropre should be free from the moral and religious connotations that are

15. "When the famous M. de La Rochefoucauld said that self-love is the principle of all our actions, how many people, ignorant as they were of the true meaning of the word selflove, did not rise against this illustrious author? They took self-love to mean pride and vanity; consequently, they imagined that M. de La Rochefoucauld held vice to be the source of all virtues. Yet it was easy to see that self-love, or the love of oneself, is nothing but a feeling that nature has engraved in us; that such feeling is transformed into a vice or a virtue within each man according to the tastes and the passions that animate him; that self-love, differently modified, can result in pride as well as in modesty."

16. "What man, if he gives up the pride of claiming a superior virtue for the pride of being more truthful, if he scrupulously looks into the recesses of his soul, will not realize that virtues and vices arise exclusively from the various ways in which self-interest is modified? That all men are driven by the same power?" (Helvétius 1758, I, II, III). 
traditionally associated with it. Yet, after arguing about the meaning of amour-propre, he takes the additional step of dispensing with the word altogether, and using a word with much less baggage: intérêt personnel, which was not widely used until the 1740s and was free of the negative overtones of amour-propre..$^{17}$ The word is perfectly suited to designate the first principle in Helvétius's doctrine: a natural impulse that is universal, morally neutral, and the cause of all human actions.

If intérêt personnel was new and relatively free of connotations in 1758 , at the beginning of the nineteenth century it was very much associated with the doctrine of Helvétius and neo-Epicureanism in general. A good witness to this fact is Mme de Staël (1807). On the one hand, she complains, in a very general way, that the nineteenth century seems to be the century of intérêt personnel: "Nous vivons dans un siècle où l'intérêt personnel semble le seul principe de toutes les actions des hommes." 18 On the other hand, she assigns a clear genealogy to this way of thinking. Staël ([1810] 1958-60, 284) distinguishes between a French philosophical school (Helvétius, Diderot, Saint-Lambert) whose ethics was based on the principle of intérêt personnel, and an English school (Shaftesbury, Hutcheson, Hume, and Smith) that rejected the selfish hypothesis:

De la morale fondée sur l'intérêt personnel.

Les écrivains français ont eu tout-à-fait raison de considérer la morale fondée sur l'intérêt comme une conséquence de la métaphysique qui attribuoit toutes les idées aux sensations. S'il n'y a rien dans l'âme que ce que les sensations y ont mis, l'agréable ou le désagréable doit être l'unique mobile de notre volonté. Helvétius, Diderot, SaintLambert n'ont pas dévié de cette ligne, et ils ont expliqué toutes les actions, y compris le dévouement des martyrs, par l'amour de soimême. Les anglais, qui, pour la plupart, professent en métaphysique la philosophie expérimentale, n'ont jamais pu supporter cependant la morale fondée sur l'intérêt. Shaftsbury [sic], Hutcheson, Smith, etc., ont proclamé le sens moral, et la sympathie, comme la source de toutes les vertus. Hume lui-même, le plus sceptique des philosophes anglais,

17. According to the ARTFL database, the earliest occurrence of interêt personnel is in Cardinal de Retz's Mémoires (1717).

18. "We live in a century in which self-interest seems to be the only principle of human actions." 
n'a pu lire sans dégoût cette théorie de l'amour de soi, qui flétrit la beauté de l'âme. ${ }^{19}$

As to the word égoïsme, it is fairly new when Garnier uses it in 1802. Like intérêt personnel, it is not common until the middle of the eighteenth century, ${ }^{20}$ and both words are often used as synonyms. ${ }^{21}$

When Roucher, Blavet, and the anonymous translator of 1778 use amourpropre to translate self-love, their choice is consistent with a philosophical tradition going back to the seventeenth century, a tradition in which English and French authors continuously respond to each other. In this dialogue, amour-propre means self-love and self-love means amour-propre. At the same time, because amour-propre and self-love are so widely used, and especially used in polemical contexts, their very definition is at stake in the constant battle between advocates and adversaries of the selfish hypothesis. Consequently, in the 1780s and 1790s, someone seeing amour-propre twice in the same paragraph of the French translation of The Wealth of Nations would, at least in some way, also remember the complicated history of the word: its longstanding association with the critique of virtues, the efforts by the philosophes to dissociate it from the critique of virtues, and Rousseau's claim that self-love is not the cause of all human actions. These connotations are roughly equivalent to the connotations of selflove in 1776: its early association with Mandeville's paradox, and the refutation of this paradox by Butler, Hutcheson, Hume, and Smith himself.

On the other hand, the words Garnier uses in 1802, intérêt personnel and égoïsme, are more univocal. They have a shorter history behind them, and they are associated with a neo-Epicurean approach that tends to explain all human behavior on the basis of a single principle: Helvétius often calls

19. "On ethical systems based on self-interest.

French writers have been quite right to see the ethical system based on self-interest as a consequence of the metaphysical doctrine that derived all ideas from sensations. If there is nothing in the soul but that which sensations have put in it, pleasure and pain must be the only motives underlying our will. Helvétius, Diderot, Saint-Lambert never deviated from this line, and they explained all actions, including the sacrifice of martyrs, by referring to the love of oneself. As to the English, even though most of them adhere to experimental philosophy when it comes to metaphysics, they have never tolerated these ethical systems based on selfinterest. Shaftesbury, Hutcheson, Smith, etc., have held that moral sense and sympathy are the source of all virtues. Even Hume, the most skeptical of English philosophers, could not read without disgust this theory of the love of oneself, which tarnished the soul's beauty."

20. According to the ARTFL database, the earliest occurrence of égoïsme is in 1757.

21. For instance: "Voilà où vous conduit le detestable intérêt personnel, l'égoïsme réduit en action" (Abbé Barruel [1781] 1830, 148). 
it intérêt personnel (self-interest) but also simply intérêt (interest), and sometimes plaisir (pleasure).

\section{Intérêt Personnel as a First Principle}

At the same time, at the beginning of the nineteenth century, the complex connotations of amour-propre are beginning to fade away, and the word is gradually restricted to the narrower meaning it has in modern French: personal vanity. This evolution appears very clearly in the successive editions of Jean-Baptiste Say's Traité d'économie politique. In the "Discours préliminaire" of the original edition (1803), Say distinguishes between vanité personnelle and intérêt personnel as motives that may cloud someone's judgments on economic issues:

De ce que l'Economie politique est l'affaire de tout le monde, naît un autre genre de difficulté: c'est qu'on a pour juges, non seulement ceux qui se sont occupés des ces matières, mais encore ceux qui n'y entendent rien. Comme chacun a donné quelques soins aux valeurs dont sa fortune est composée, chacun se croit en droit d'avoir une opinion sur les valeurs, une opinion qui se trouve exaltée par la vanité personnelle, comme toutes les opinions, et de plus par l'intérêt personnel, qui, à notre insu, exerce tant d'empire sur nos jugements. $(1: \mathrm{xl})^{22}$

In the second edition (1814) Say proposes a variation on the same thought, but the keywords are almost the same:

Les opinions en économie politique ont même ce malheur particulier, c'est qu'elles ne se trouvent pas seulement soutenues par la vanité, la plus universelle des infirmités humaines, mais par l'intérêt personnel qui ne l'est guère moins, et qui, à notre insu, et malgré nous, exerce tant d'empire sur notre façon de penser. (1:lxviij) $)^{23}$

22. "The fact that political economy is everybody's business causes another kind of difficulty: one is judged not only by those who have studied these matters, but also by those who misunderstand them entirely. Since everybody has given some thought to the investments that make up his own wealth, everybody thinks he is entitled to an opinion on investments, an opinion that happens to be exalted by personal vanity [vanité personnelle], as all opinions are, and also by self-interest [intérêt personnel], which influences our judgments so greatly, and in ways we do not realize."

23. "Opinions in political economy have the distinct misfortune of being sustained not only by vanity [vanité] (the most universal of human weaknesses) but also by self-interest [intérêt personnel], which isn't much less universal, and influences our manner of thinking so greatly, and in ways we cannot help and do not realize." 
In the fifth edition (1826), however, a major change occurs:

Lorsqu'une fois un auteur a manifesté une opinion, la vanité, la plus universelle des infirmités humaines, veut qu'il la soutienne. L'intérêt personnel se joint quelquefois à l'amour-propre; et l'on sait quelle influence il exerce, même à notre insu, sur nos opinions. De là les doctrines hasardées qu'on voit naître chaque jour et les objections qu'on reproduit après qu'elles ont été cent fois réfutées. $(1: \mathrm{xc})^{24}$

In 1826, the meaning of amour-propre has diverged so much from the meaning of intérêt personnel that Say does not hesitate to use both words in the same paragraph in order to designate psychological motives that work together but are entirely distinct. In fact, it can be shown that the modern meaning of amour-propre was present in Say's thinking as early as 1817. In the first edition of his small volume on morals and customs, Say $(1817,83)$ made a clear distinction between amour-propre and intérêt, and he equated amour-propre with vanity:

Les philosophes moralistes paraissent croire que l'amour de soi, l'intérêt, dirige les actions des hommes plus que ne le fait l'amour-propre, la vanité. Je pense au contraire que la vanité exerce sur eux plus d'empire, généralement parlant, que l'amour de soi. Il suffit d'observer dans combien de cas les hommes agissent par vanité d'une manière opposée à leurs intérêts, depuis l'enfant qui blessé d'une mortification qu'on lui a fait essuyer, boude contre son ventre, jusqu'au potentat à qui l'on fait faire tant de sottise en le flattant, et qui détruit son pays, c'est-àdire le fondement de sa puissance pour se venger d'une insulte de gazette. $^{25}$

24. "Once an author has professed an opinion, vanity [vanité], the most universal of human weaknesses, causes him to defend it. Self-interest [intérêt personnel] sometimes supplements self-importance [amour-propre]: it is well known how much it affects our opinions, even when we do not realize it. Hence these haphazard doctrines we see cropping up every day, and the objections one sees repeated even after these doctrines have been refuted a hundred times."

25. "Moral philosophers seem to believe that the love of oneself [amour de soi], or selfinterest [intérêt], drives the actions of men more than self-importance [amour-propre], or vanity [vanité]. I believe, on the contrary, that vanity has more power over them, generally speaking, than the love of oneself. It suffices to observe how many times men act out of vanity in a way that is contrary to their interests, from the child whose pride was wounded by some punishment and who reacts by abstaining from eating, to the potentate who can be flattered into making so many silly decisions and who destroys his country, i.e., the foundation for his power, in order to hit back those who insulted him in a gazette." 
In this passage, amour-propre is explicitly presented as a synonym for vanité. Another remarkable example of the same use of amour-propre can be found in Say's $(1825,578)$ reply to Storch's accusation of plagiarism:

Dans ces notes, je crois ne m'être écarté en rien des égards que se doivent deux écrivains qui, avec des intentions droites, cultivent la même science. L'amour-propre un peu trop susceptible de M. Storch n'en a pas jugé ainsi. ${ }^{26}$

In these two examples as in the 1826 version of the Traite d'économie politique, amour-propre (self-importance) has to do with self-image, selfdelusion, and irrational behavior, and its connotation is entirely negative. Intérêt personnel (self-interest) is more ambiguous. On the one hand, it is the impulse that causes us to prefer ourselves to others and makes us biased in the evaluation of the opinions we profess; on the other hand, it is the drive behind economic activity, the motive that prompts human beings to save and invest. When Say elaborates on the parts of The Wealth of Nations that discuss the role of private interests in the optimal allocation of capital, he uses the word intérêt personnel:

Il est heureux que l'intérêt personnel veille sans cesse à la conservation des capitaux des particuliers, et qu'on ne puisse en aucun temps distraire un capital d'un emploi productif, sans se priver d'un revenu proportionné.

Smith pense qu'en tout pays, la profusion ou l'impéritie de certains particuliers, et des administrateurs de la fortune publique, est plus que compensée par la frugalité de la majorité des citoyens, et par le soin qu'ils prennent de leurs intérêts. $(1841,116)^{27}$

Similarly, in a passage that develops Smith's view on the freedom of trade, Say argues that the criterion for deciding whether a particular good should be purchased locally or imported is intérêt personnel:

26. "In these notes, I think I have never failed to show the respect that two well-meaning writers who cultivate the same science owe one another. Mr. Storch's over-sensitive vanity disagrees."

27. "It is fortunate that self-interest [intérêt personnel] should constantly take care of the preservation of private capital, and that it should be impossible to divert some capital from a productive use without forfeiting the corresponding income.

Smith believes that in every country, the profligacy and incompetence of some individuals and of the administrators of the public's wealth is more than offset by the frugality of the majority of the citizens and by the care with which they attend to their own interests [leurs intérêts]." 
Le sacrifice au prix duquel nous obtenons des étrangers cette matière première, n'a rien de plus fâcheux que le sacrifice des avances et des consommations que nous fesons en chaque genre de production pour obtenir un nouveau produit. L'intérêt personnel est toujours le meilleur juge de l'étendue de ce sacrifice et de l'étendue du dédommagement qu'on peut s'en promettre; et quoique l'intérêt personnel se trompe quelquefois, c'est, au demeurant, le juge le moins dangereux, et celui dont les jugemens coûtent le moins. $(1841,156)^{28}$

The importance of the concept of intérêt personnel for French readers of Smith at the beginning of the nineteenth century is underscored by the presence of an index entry titled "INTÉRÊT privé ou personnel" in the Garnier translation in 1802. The entry refers to four passages in The Wealth of Nations where Smith discusses the relationship between private interests and the public interest, and the role of private interests in the optimal allocation of capital:

INTÉRÊT privé ou personnel. Dans l'état de liberté, dirige l'industrie vers la route la plus profitable à toute la société. III, 58. Et tout capital vers l'emploi le plus conforme à l'intérêt général. Id, 435. Est un guide plus sûr, à cet égard, que tout homme d'Etat ou législateur quelconque. $I d$., 60. Ce concours entre l'intérêt privé et l'intérêt public est dérangé par les réglemens du système commercial, et comment. Id., $436 .{ }^{29}$

Remarkably, in the index that appears for the first time in the third edition of The Wealth of Nations (1784), ${ }^{30}$ there is no such entry. Self-interest or private interest are nowhere mentioned as keywords. ${ }^{31}$ On the other hand, this index has an entry for self-love, defined as "the governing principle

28. "The sacrifice involved in obtaining this commodity from abroad is not more painful than the sacrifice involved in the investment and consumption necessary to obtain a new product. Self-interest [intérêt personnel] is always the best judge to determine how large the sacrifice is and how large the corresponding reward must be; even though self-interest [intérêt personnel] is sometimes mistaken, it is still the safest judge, and the least costly."

29. "INTEREST (Private or Self-) [INTÉRÊT (privé ou personnel)]. In the state of liberty, directs the industry on the path most profitable to society as a whole. III, 58. And all capital toward the use most consistent with the public interest. Id., 435. Is a better guide, in that respect, than any statesman or legislator. $I d ., 60$. This agreement between private interest and the public interest is disturbed by the regulations of the commercial system. How. Id., 436."

30. See Haakonssen and Skinner 2001.

31. There is an entry for interest in the sense of monetary interest. See Haakonssen and Skinner 2001, 193. The word self-interest appears only once in The Wealth of Nations, in the context of a discussion of religion (v.i.g.2). 
in the intercourse of human society" (Haakonssen and Skinner 2001, 203). The reference is of course to the only passage where the word appears, the second chapter of book 1 , which discusses the causes of the division of labor.

Why is self-love a keyword, while there is no entry for words like interest, private interest, or self-interest? It is because the word self-love is used in the only passage in The Wealth of Nations where Smith discusses (or at least comes close to discussing) first principles. ${ }^{32}$ As we have seen before, self-love is a widely used concept that is almost always used as a first principle in eighteenth-century moral philosophy. On the other hand, if we check the passages where Garnier uses avantage personnel or intérêt personnel against the original English, we will find that Smith uses expressions like his own advantage or his own interest. The passage that the Garnier index summarizes as "INTÉRÊT privé ou personnel. Dans l'état de liberté, dirige l'industrie vers la route la plus profitable à toute la société" is the very famous passage where the invisible hand appears. Here is how it reads in Garnier:

En cela, comme dans beaucoup d'autres cas, il est conduit par une main invisible, pour remplir une fin qui n'entre nullement dans ses intentions; et ce n'est pas toujours ce qu'il y a de plus mal pour la société, que cette fin n'entre pour rien dans ses intentions. Tout en ne cherchant que son intérêt personnel, il travaille souvent d'une manière bien plus efficace pour l'intérêt de la société, que s'il avait réellement pour but d'y travailler. $^{33}$

In the original English, the expression that corresponds to "tout en ne cherchant que son intérêt personnel" is "by pursuing his own interest." In French, intérêt personnel sounds very much like a basic concept, a first principle that deserves its own entry in the index. This is confirmed by the fact that Jean-Baptiste Say, the leading interpreter of Smith at the time, uses interrêt personnel whenever he elaborates on the passages from book 4 of The Wealth of Nations that are mentioned in Garnier's index entry. In the original English, however, it is much more difficult to read an expression like his own interest as a basic concept, especially since there is no entry for words like personal interest or self-interest in the index. Only the passage from book 1 where the word self-love appears can be construed as referring to first principles.

32. For a discussion of the status of self-love as a first principle in The Wealth of Nations, see Force 2003, 121-34.

33. Translation of The Wealth of Nations, IV.ii.9. 
This is where Garnier's choice of intérêt personnel instead of amourpropre has the weightiest consequences. In all previous translations, amourpropre appeared only at the beginning of the book, just as self-love does in the original. In the Garnier translation, interêt personnel appears not only at the beginning (to translate self-love), but also in book 4 (to translate his own interest). Thanks to the use of an identical word, a conceptual connection is established between the principle underlying the division of labor (in book 1), and the principle underlying saving and investment (in book 4). This connection is established not only with the specific passage in book 4 where Garnier uses intérêt personnel, but also in the many passages in book 4 where Garnier uses intérêt and intérêts privés to translate Smith's analysis of the relationship between private interests and the public interest. Whereas Smith uses a variety of words and concepts, Garnier uses just one: intérêt personnel. Translate intérêt personnel back into English: instead of the variety of words Smith uses, you will have only one word, self-interest. In Garnier's translation, Smith's system seems to be entirely derived from the axiom of self-interest. This axiomatic coherence (which is far from obvious in Smith's original text) is of course characteristic of the orthodox school that developed in the first half of the nineteenth century. What is remarkable is that many years before there was an orthodox school, its assumptions regarding self-interest were already present in Garnier's translation.

It would of course be an exaggeration to claim that Garnier's translation is the prime motivating factor behind the conventional reading of The Wealth of Nations: self-interest is the first principle of Smith's doctrine and of economic science in general. ${ }^{34}$ I would simply submit that Garnier's choice of words and Say's enthusiastic endorsement of this choice are an early manifestation of what would later cohere into the modern, conventional reading of Smith. When economics asserted itself as a science in the nineteenth century, it relied on Bentham, rather than Smith, for its psychological assumptions. It that sense, the psychological underpinnings of orthodox economic theory were neo-Epicurean, and, beyond Bentham, they could be traced back to Helvétius. As Henry Sidgwick put it in 1877, "The premises of Bentham are all clearly given by Helvetius," whose psychological theory was very clear and simple:

Helvetius puts with a highly effective simplicity, from which Hume was precluded by his more subtle and complex psychological analysis,

34. For instance, see Stigler 1971, 265, which characterizes The Wealth of Nations as "a stupendous palace erected upon the granite of self-interest." 
these two doctrines: first, that every human being "en tout temps, en tout lieu" seeks his own interest, and judges of things and persons according as they promote it; and secondly, that, as the public is made up of individuals, the qualities that naturally and normally gain public esteem and are called virtues are those useful to the public. (638)

Given the widespread acceptance of these psychological assumptions among economists, it is not surprising that The Wealth of Nations was read and interpreted from a neo-Epicurean or utilitarian point of view. This produced a number of puzzles, the most famous being the "Adam Smith problem," which was initially formulated by Lujo Brentano in 1877. Brentano perceived a contradiction between the explicit rejection of the selfish hypothesis in The Theory of Moral Sentiments and what he saw as an endorsement of the same hypothesis in The Wealth of Nations. He accounted for the discrepancy by supposing that, after writing The Theory of Moral Sentiments, Smith had discovered and adopted the views of Helvétius on self-interest. According to Brentano (1891, 64), The Wealth of Nations was based on the psychological theory of Helvétius:

In the "Investigations into the Wealth of Nations," on the contrary, he holds entirely to the views of the book of Helvetius upon the nature of man, and regards selfishness as the only motive of human action. The consequences of this dogma of selfishness permeate almost all parts of his work. ${ }^{35}$

The idea that Smith might have borrowed from the philosopher of selfinterest was discarded a long time ago (see Oncken 1897). Still, this reading of Smith is quite plausible if one uses the French translation (as many nineteenth-century economists did) instead of the original.

\section{References}

Abbé Barruel. [1781] 1830. Les Helviennes. Paris: Poilleux.

Brentano, Lujo. 1891. The Relation of Labor to the Law of Today. New York: G.P. Putnam's Sons.

Cardinal de Retz. 1717. Mémoires de Monsieur le Cardinal de Retz. Amsterdam: Jean-Frédéric Bernard.

Carpenter, Kenneth E. 2002. The Dissemination of The Wealth of Nations in French and in France 1776-1843. New York: The Bibliographical Society of America. 
Desrenaudes, Martial Borye. 1802. Review of Germain Garnier's translation of The Wealth of Nations. La Décade philosophique, littéraire et politique, no. 36, 17 September.

de Staël, Germaine. 1807. Corinne, ou de l'Italie. London: Peltier.

- [1810] 1958-60. De l'Allemagne. Paris: Hachette.

Force, Pierre. 2003. Self-Interest before Adam Smith: A Genealogy of Economic Science. Cambridge: Cambridge University Press.

Fuchs, Hans-Jürgen. 1977. Entfremdung und Narzißmus: Semantische Untersuchungen zur Geschichte der "Selbstbezogenheit" als Vorgeschichte von französisch “amour-propre.” Stuttgart: Metzler.

Garnier, Germain, trans. 1802. Recherches sur la nature et les causes de la richesse des nations, par Adam Smith, traduction nouvelle avec des notes et observations, par Germain Garnier, de l'Institut national. Paris: Agasse.

Haakonssen, K., and A. S. Skinner. 2001. Index to the Works of Adam Smith. Oxford: Clarendon Press.

Helvétius, Claude-Adrien. 1758. De l'Esprit. Paris: Durand.

Hume, David. [1751] 1983. Enquiry Concerning the Principles of Morals. Edited by J. B. Schneewind. Indianapolis: Hackett.

La Rochefoucauld, François de. 1665. Maximes. Paris: Barbin.

Mandeville, Bernard. 1732. The Fable of the Bees, or Private Vices, Public Benefits. 6th ed. London: J. Tonson.

Marx, Karl. 1981. Exzerpte aus Adam Smith: Recherches sur la nature et les causes de la richesse des nations. Vol. 4, sec. 2, pp. 332-87, of MEGA (Marx-Engels Gesamtausgabe). Berlin: Dietz Verlag.

—. 1982. Ökonomisch-philosophische Manuskripte. Vol. 1, pt. 2, pp. 189-438, of MEGA (Marx-Engels Gesamtausgabe). Berlin: Dietz Verlag.

Oncken, August. 1897. The Consistency of Adam Smith. Economic Journal 7.27:443-50.

Recherches sur la nature et les causes de la richesse des nations, traduit de l'anglois de M. Adam Smith, par M***. 1778. The Hague.

Roucher, Jean Antoine, trans. 1790. Recherches sur la nature et les causes de la richesse des nations, traduites de l'anglois de M. Smith, sur la quatrième édition, par M. Roucher; et suivies d'un volume de notes, par M. le Marquis de Condorcet, de l'Académie Françoise, et Secrétaire perpétuel de l'Académie des Sciences. Paris: Buisson.

Saint-Lambert, Jean-François, Marquis de. 1751-72. Encyclopédie ou dictionnaire raisonné des sciences, des arts et des métiers. 17 vols. Paris.

Say, Jean-Baptiste. 1803. Traité d'économie politique. Paris: Deterville.

—. 1814. Traité d'économie politique. 2nd ed. Paris: Renouard.

- 1817. Petit volume concernant quelques aspects des hommes et de la société. Paris: Deterville.

- 1825. Réclamation.-Aux auteurs de la Revue encyclopédique. Revue encyclopédique, vol. 25, February.

—. 1826. Traité d'économie politique. 5th ed. Paris: Rapilly. 
1841. Traité d'économie politique. 6th ed. Paris: Guillaumin.

Sidgwick, Henry. 1877. Bentham and Benthamism in Politics and Ethics. Fortnightly Review, no. 21:627-52.

Smith, Adam. [1776] 1784. An Inquiry into the Nature and Causes of the Wealth of Nations. 3rd ed. London: Strahan and Cadell.

. [1759] 1976. The Theory of Moral Sentiments. Edited by D. D. Raphael and A. L. Macfie. Vol. 1 of The Glasgow Edition of the Works and Correspondence of Adam Smith. Oxford: Oxford University Press.

. [1776] 1976. An Inquiry into the Nature and Causes of the Wealth of Nations. Edited by R. H. Campbell and A. S. Skinner; textual editor W. B. Todd. Vol. 2 of The Glasgow Edition of the Works and Correspondence of Adam Smith. Oxford: Oxford University Press.

Stigler, George J. 1971. Smith's Travels on the Ship of State. HOPE 3.2:265-77.

Storch, Heinrich. 1815. Cours d'économie politique, ou exposition des principes qui déterminent la prospérité des nations. 6 vols. St. Petersburg: Pluchart.

Taieb, Paulette, trans. 1995. Enquête sur la nature et les causes de la richesse des nations, by Adam Smith. 4 vols. Paris: PUF.

Tribe, Keith. 2003. Continental Political Economy from the Physiocrats to the Marginal Revolution. In vol. 7 of The Cambridge History of Science, edited by Theodore M. Porter and Dorothy Ross. Cambridge: Cambridge University Press.

Tribe, Keith, and Hiroshi Mizuta, eds. 2002. A Critical Bibliography of Adam Smith. London: Pickering \& Chatto.

Voltaire. [1764] 1954. Dictionnaire philosophique. Edited by J. Benda and R. Naves. Paris: Garnier. 